G 201 臨床病期 I 期非小細胞肺癌に対する縮小手術 の検討

三重大学医学部胸部外科

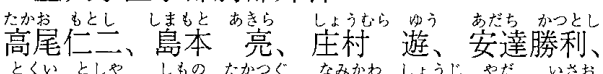
徳井俊也、下野高嗣、普河尚二、矢田

【目的】臨床病期 I 期非小細胞肺癌に対する縮小手術 の妥当性を評価する。【対象】原発性肺癌手術症例 1214 例中、79例(6.5\%)に縮小手術を行った。このうち、臨床 病期 $I$ 期非小細胞肺癌49例(62\%)の遠隔予後を検討した。 内訳は腺癌 24 例、扁平上皮癌22例、その他3例で、腫瘍 径が2 $\mathrm{cm}$ 以下のものは腺癌で10例 $(42 \%) 、$ 扁平上皮癌で7 例(32\%)であった。術式は部分切除27例、区域切除22例 で、6例にR2 郭清を行ったが、他はピックアップのみで あった。術後病理期分類では、T3が4例、N1,N2が1例づ つあった。【結果】全体の5年生存率は癌死のみで $72.3 \%$ 、 実測で64.8\%と I 期非小細胞肺癌に対する定型術式の予 後と同等であった。術後癌死は7例で、そのうち5例が局 所再発であった。これらの腫瘍径は全例 $2 \mathrm{~cm}$ 以上で、局 所再発の5例中4例は腺癌で、DNA分析でいずれも ancuploidyを示した。生存率の比較では、有意ではない ものの、扁平上皮癌、腫瘍径 $2 \mathrm{~cm}$ 以下、区域切除で予後 良好であった。【結語】臨床病期 I 期非小細胞肺癌に対 する縮小手術は、定型術式と同等の遠隔予後を示した。 しかし、腺癌で腫瘍径 $2 \mathrm{~cm}$ 以上、 aneuploidyは局所再発の high risk 群であり注意を要する。

\section{G 203} 肺癌に対する縮小手術の適応 一術前診断、手術所見、予後からの檢討一

大阪市立総合医療セン多一眊吸器外科、

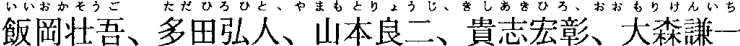

【目的】高齢者、心肺機能障害者では肺癌手術の葉切 が臨床的に困難之判断される例が少なくない。縮小手 術の適心について自験例を検討する。【対象】過去 3 年間の肺癌手術368例のうち、35例 (37 側 : 同時 1 例、 異時 1 例）に区域ないし部分切除を施行した。男29例 (両側 2 ) 、女 6 例。年蛉は43-85歳、うち75歳未満 18例、75-79歳 8 例（9 侧）、80歳以上 9 例 (10側) である。縮小手術適用理由は低肺機能: 19例、高齢 5 例、 他臟器疾患合併 6 例、雨側 2 例、pm2: 2 例。他 1 例。 術式は区切15例、開胸部切16例、VATS部切 6 例。組 織型は腺癌 11 側、扁平上皮癌 21 側、その他 5 例。CT上 腫瘍径 $2 \mathrm{~cm}$ 以下 8 例、 $2-3 \mathrm{~cm}: 15$ 例、 $3 \mathrm{~cm}$ 以上 14 例。 腫瘍から肺門血管までの距離 $2 \mathrm{~cm}$ 以下 5 例は全例が区 切、2-33 cmの 7 例は 4 例が区切、 2 例が部切、1 例が $\mathrm{V}$ 部切。【結果】術後追跡期間は 2 34力月、中間値 は 18 力月、再発 6 例（局所 5 例）、死亡 3 例（癌死 2 例)。部切 1 例之 $V$ 部切 1 例が断端。他の $V$ 部切 5 例 は距離が $4 \mathrm{~cm}$ 以上、うち径 $2 \mathrm{~cm}$ 以下ではenbloc切除、 しかし径 $3.5 \mathrm{~cm} の 1$ 例（腺癌）は局所再発した。 $\mathrm{pm} 2$ の 2 例は再発。【結語】尰瘍径が $3 \mathrm{~cm}$ を越えるとV部切 が、肺門距離が $3 \mathrm{~cm}$ 以下例では部切の適用には Surgical Marginを留意した手技が重要である。

\section{2 原発性肺癌縮小手術症例の検討}

国立療養所西群馬病院外科 ${ }^{1}$ 、群馬大学第二外科 ${ }^{2}$ 平茾利箱 ${ }^{1}$ 、川島 修 ${ }^{1}$ 、上吉原光宏 ${ }^{1}$ 、森下靖雄 ${ }^{2}$

【目的】低心肺機能患者、高齢者が主な対象となる肺 癌縮小手術についてその意義を検討した。

【対象】過去16年間の当院における原発性肺癌手術症 例666例中、縮小手術が絶対的非治癒切除亡なったも の、術後再発肺癌・多発肺癌に対して行われたものを 除外した14症例 ( $2 \%$ )を対象とした。性別は男性 6 例、女性 8 例、年齢は63〜 89歳(平均75歳)であった。

【結果】組織型は腺癌 9 例、扁平上皮癌 2 例、大細胞 癌 2 例、腺扁平上皮癌 1 例であった。術前全ての症例 が I 期と診断された。術式は、術後病理で最大腫瘍径 が3. $0 \mathrm{~cm}$ 以下の12例には部分切除術が、3.0 cmを越えた 2 例には区域切除術が行われていた。1996年12月まで の転㷌は死亡 8 例、生存 6 例である。死亡例 6 例亡生 存例 1 例に肺癌の再発を認めた。これらの初再発部位 は、隣接肺 4 例、近傍肺 1 例、近傍肺之同側他肺 1 例、両側肺 1 例であり、再発時期は術後 $4 \sim 44$ 力月で あった。組織学的に、再発例 7 例の全ての症例で脈管 侵襲が認められた。Kaplan-Meier法により算出した 5 年生存率は68\%であった。

【結語】5年生存率からみると、機能的に標準術式が 困難な症例に縮小手術は有意義であるが、局所再発の 点からリスクのない症例には不適切之考えられた。

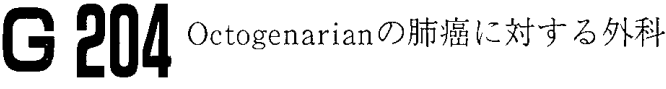

三重大学医学部胸部外科。

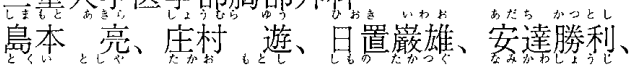
德井俊也、高尾仁二、下野高嗣、並河尚二、 矢田公

【目的】80歳以上の超高齢を手術危険因子の一つと考え、原 発性肺澏に対する縮小手術の積極的適応とする我々の方針を 検討した。

【対象】原発性肺癌手術症例 1230 例中、80歳以上の超高齢者 36例(2.9\%)を対象とし、術後成績を検討した。

【結果】1980年以来80歳以上の超高齢者に対しても手術を施 行しているが、病理病期はI期 22 例(61.1\%)、II期 5例(13.9\%)、 IIIA期9例(25.0\%)で、術式は葉切除27例(75.0\%)、部分切除9例 (25.0\%) と、超高齢者に対しては早期症例、低侵襲術式を選択 している。癌関連死亡(術後合併症による在院死を含む)による 5 年生存率に有意差を認めなかった 80 歳以上 $42 \%$ 、全症例 38 $\%) 。$ 一方、術後早期合併症は75歳以上で有意に多く、80歳以 上では 14例 $(38.9 \%)$ と高率であった。術後1ヶ月以内死亡は認 めなかったが、術後 1 年以内の非癌死亡は75歳以上で有意に多 く、80歳以上では5例(13.9\%)でその主因は肺炎であった。

【結語】80歳以上の超高齢者に対する原発性肺癌手術では、 80 歳以上を手術危険因子の一つとして扱う我々の方針により 術後急性期死亡を認めず、他病死を除いた生存率も他の年齢 層と同等であり、妥当であると考えられた。 